\title{
Demand forl Consumption of Culture Advertising Photography
}

\author{
Sibila Petenji Arbutina and Jelena Kovačević Vorgučin \\ The Higher Technical School of Professional Education, \\ Novi Sad, Serbia
}

sibila.petenji.arbutina@gmail.com; jelka.photo@gmail.com

\begin{abstract}
This paper sets out to point to the way art is presented in the society, as well as to the way cultural needs are met, developed and encouraged. Special attention is paid to different types of communication through art and design and also to the information passed between a producer and a consumer by means of advertising photography.

Analyzing the context in which a photograph as an information medium is located, we will tackle the problem of acceptance or rejection of a certain advertisement, and the way it spreads the awareness of the current social issues in the campaigns whose ultimate goal is profit, the issue off counter-advertising, and the strategy of shocking as a way of expression.
\end{abstract}

Keywords: art presentation, cultural needs, communication, documentary photography, campaign, shock advertising, campaign performance, success of a campaign

\section{Introduction}

The following text is focused on the analysis of the Benetton campaigns, which have had an absolutely stunning effect worldwide. The paper refers to the use of a photograph as means of conveying an idea and attitude representing the company. What has successfully distinguished Benetton's campaigns in the advertising universe for decades now is a clear photo, sometimes containing a discreet text message, rich in informative contents. Special attention is paid to Oliviero Toscani, a controversial photographer of Benetton's controversial campaigns.

The success of a campaign is a problem the following text focuses on. In which way a company's message is to be interpreted depending on a region, whether it is clear or ambiguous, whether a campaign is to sell the product well - these are the questions which often cannot be definitely answered for sure even by the very creators of the campaign.

Material published as part of this publication, either on-line or in print, is copyrighted by the Informing Science Institute. Permission to make digital or paper copy of part or all of these works for personal or classroom use is granted without fee provided that the copies are not made or distributed for profit or commercial advantage AND that copies 1) bear this notice in full and 2) give the full citation on the first page. It is permissible to abstract these works so long as credit is given. To copy in all other cases or to republish or to post on a server or to redistribute to lists requires specific permission and payment of a fee. Contact 0HPublisher@InformingScience.org to request redistribution permission.

\section{Cultural Needs}

Business management and cultural management are flatly opposed with respect to the fundamental standards found in their interest basis. While business management is focused on generating profit, giving the product itself secondary importance, cultural management on the other hand places vital importance on 
work, while profit as its secondary aim is often connected to self-sustainability of a mere organisation (Dragicevic Sesic \& Dragojevic, 2005).

Cultural management deals with culture as a system within which direct human activities provide the conditions for cultural and especially art creativity, the forms of its presentation and its acceptance by the general public (Gidens, 2005). If such activities are to be successfully conducted in a society, it is necessary to perceive cultural needs of the general public.

What is meant by cultural needs includes the basic needs for linguistic expression and communication, the need for learning, i.e. for broadening one's mind, the need for beauty in everyday life, and, of course, the need for aesthetic experience and visual expression.

More and more often, audience is seen not as a passive object, but as an active participant that has an opportunity to interact, thus upgrading its cultural needs. In the modern world of many opportunities for acquiring knowledge and information, Dragicevic Sesic, professor of the Faculty of Drama Arts in Belgrade, and Stojkovic, a professor at the Faculty of Political Sciences in Belgrade say "... a man of modern society does not live in a global village, but in his/her interests ..." (Dragicevic Sesic \& Stojkovic, 2007).

Rapid development of people's aesthetic needs in everyday life has led to implementation of the visual arts in our daily life. The 20th century is characterized by the development of design and applied art, and the idea "art for the sake of art" (l'art pour l'art) is replaced more and more often with the concept of "art for advertising."

The authors believe that with the development of advertising, the overlapping of business and cultural management occurs, which merges the striving for profit together with highlighting the importance of artistic work.

\section{Interactivity of Advertising Photography}

A photograph has proved to be one of the best solutions in terms of conveying a message, due to the fast pace of life, tremendous development of technology, and the need for fast acquisition of information. A photograph as a kind of visual information shows one part of reality in the most realistic way. However, full consideration must be given to the context in which it is placed.

In order to decode photographs and advertising images in a more efficient way, it is necessary to be familiar with their context.

It is necessary to explain the difference between the approach of commercial photography and that of a documentary photography. The aim of a commercial photograph is profit. Therefore, from the very beginning a photographer is limited to a set topic and to the psychological and sociological conditions as dictated directly by the market. A photographer has to be familiar with the target group to which the product or advertisement should be sold.

David E. Nye, a professor of American History at the University of Southern Denmark explained the difference between documentary and commercial photography in the following way: "Comparing photographs of socially engaged photographers, documentarists, with works of commercial photographers, despite the obvious documentary appearance of both, I can find the difference between them even when they treat the same subject."

He also observes that "the need to present different things to different target groups has influenced the production of images for various publications. For e. g., scientific journals have emphasized the development of machines, while publications intended for workers use images based on the idea that a whole corporation is one amicable community" (Nye, 1985). 
Taking into consideration that the prerequisites for the progress art are the introduction of innovations, and stepping 'outside the boundary', we will analyze the shocking effect of the Benetton ad campaign, point out its novel approach to advertising photography, where art retains its basic principles, and advertising images use the attributes of the documentary photography genre.

\section{Photograph and Context, Shock Advertising}

\section{Toscani's Initial Campaigns for the Company of Benetton}

Since its foundation, Benetton company has tried to talk to young people, the "more socially conscious clothing buyers than other age groups", as Paul Martin Lester, full professor of Communications at California State University, Fullerton (Lester, 2006) once put it. In launching a trade brand intended for young people, in their advertising campaign they used photography as a medium that allows direct communication. In the beginning, Benetton campaigns were characterized by traditional commercial photography, seemingly without markup applied context. Pictures shot in the studio represent young people of all races, dressed in Benetton (see Figure 1). We believe that clear and bright colors as a basic emotional principle, which also characterizes Benetton fashion products (United colors) is ambiguous. Does it refer to the united colours of all races - meaning let's unite the planet - or to the united colours meaning colours that we can see? This is combined with the lovely youngsters as models. Youth and beauty were the main concepts of the campaign.

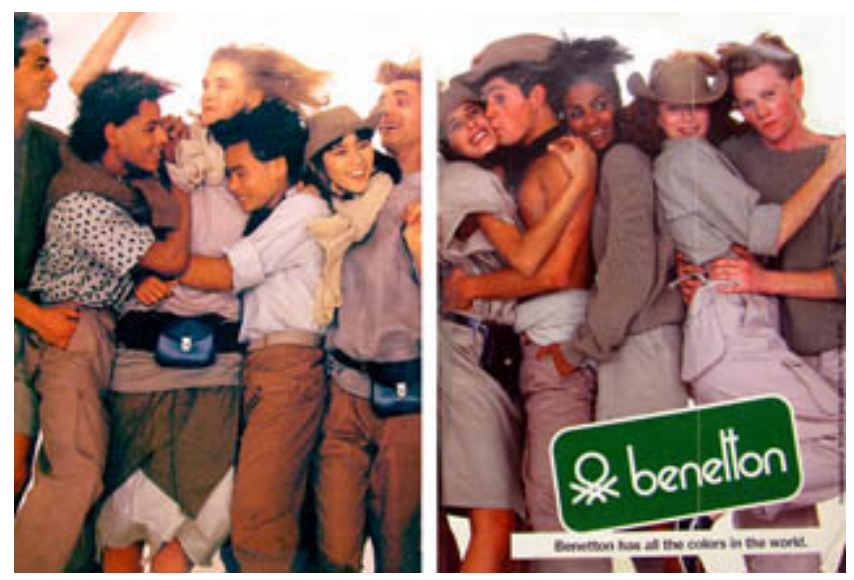

Figure 1. Crowd, Benetton Group, 1984.

Source: http://www.commercialcloset.org

Photographs of this type are later repeatedly used in their product catalogues. Instead of of the product, Benetton presented powerful and problematic visual images of social issues of universal important social issues such as environmental disasters, peace, AIDS, terrorism, murder, tolerance of diversity and struggle against racism. Benetton's advertising campaigns and social communication strategies are a clear echo of contemporary culture and society. Benetton's United Colors Campaign transformed the traditional notions of advertising, so that the goal is no longer only to simply sell the products, the brand name or to create desire. As stated at Docshare, site for document sharing: "Instead, their campaigns promote social concerns, critiques and ideologies." (Docshare, 2009) 


\section{Analysis of Differences of Photography Contexts}

Toscani's Benetton advertising campaign enables us to examine numerous strategies for an understanding of the advertising photography, and to explain the symbolism, social status and general approach to art, meaning and information.

Oliviero Toscani, designer, photographer and creative director of the company Benetton, has become respected in the world of art through his photos for this fashion house.

1984, Toscani joined the company of Benetton and The United Colours campaign started. There was no deep significance attached to the beginning of the campaign - the young from all corners of the world were wearing Benetton clothes. "In March 1987, the advertisement taking up more than four pages of the magazine featured a Russian boy who was parading wearing red-coloured clothes of Benetton along with Soviet insignia and Stacey Reynolds, an American girl wearing clothes made of denim." (The Face, march 1987, as cited in Wells, 2006). Toscani adopts different attitudes towards the USA and USSR through different poses and insignia that his models wear (Ramamurthy, 2003). The Soviet boy is serious-faced (he loses an attribute of a cheerful child, shown without a smile) and is holding a paper-made rocket in standard combat colours in his left hand. The symbolism is probably aimed at the arms race. In total opposition to him, there stands an American girl with gentle, childlike smile on her face holding a Statue of the Liberty model in her hand. In a very bold and intriguing way, Toscani indirectly mingles politics and individual attitudes towards the concept of difference. The presentation of the USA as being gentle and the USSR as being strong and uncompromising implies that the USSR is responsible for intensive investment in arms.

This message clearly shows who are Benetton and Toscani are aiming at, i.e. who they identify as their advertisement's market - affluent and docile America should be an appropriate market. Within this series of advertisement, there is also a photo of a Chinese boy, dressed in blue, carrying Mao's "little red book" turned upside-down. Accoring to Ramamurthy "Advertising is the poetry to imperialism" (2003, p.219-210). Such advertisements, of course, support ideological interest of the company of Benetton: "Our international reputation and the core value of our company are the same thing - a global group open for reception of worldwide impact and engaged in a continuous search for setting new limits" (Benetton, 1993, as cited in Wells 2006).

Until 1989, apart from Toscani's bold photographs relating to "politics", his work for a fashion campaign was marked by docile studio photos made as a neutral background for the models wearing Benetton clothes.

However, Toscani, as an extremely controversial and bold photographer tries to make changes to his advertising photography and turns his attention to creation of a picture that is going to convey directly its social message, but indirectly its commercial message. He considers literal conveying of information as an inadequate way for the company to generate profit. The advertising analysts called the period from 1989 to 1991 the phase of "racial discrimination and ambiguity", as Back and Quaade stated (1993, p.65).

The next period of Toscani's engagement in Benetton campaign is characterised by directed studio photography. The photo of a black woman who breastfeeds a white baby (see Figure 2), which was used in Benetton campaign in 1989, evoked a series of controversial reactions. From the initial idea to 'join the planet' the message was later on reduced to a completely different essence. 


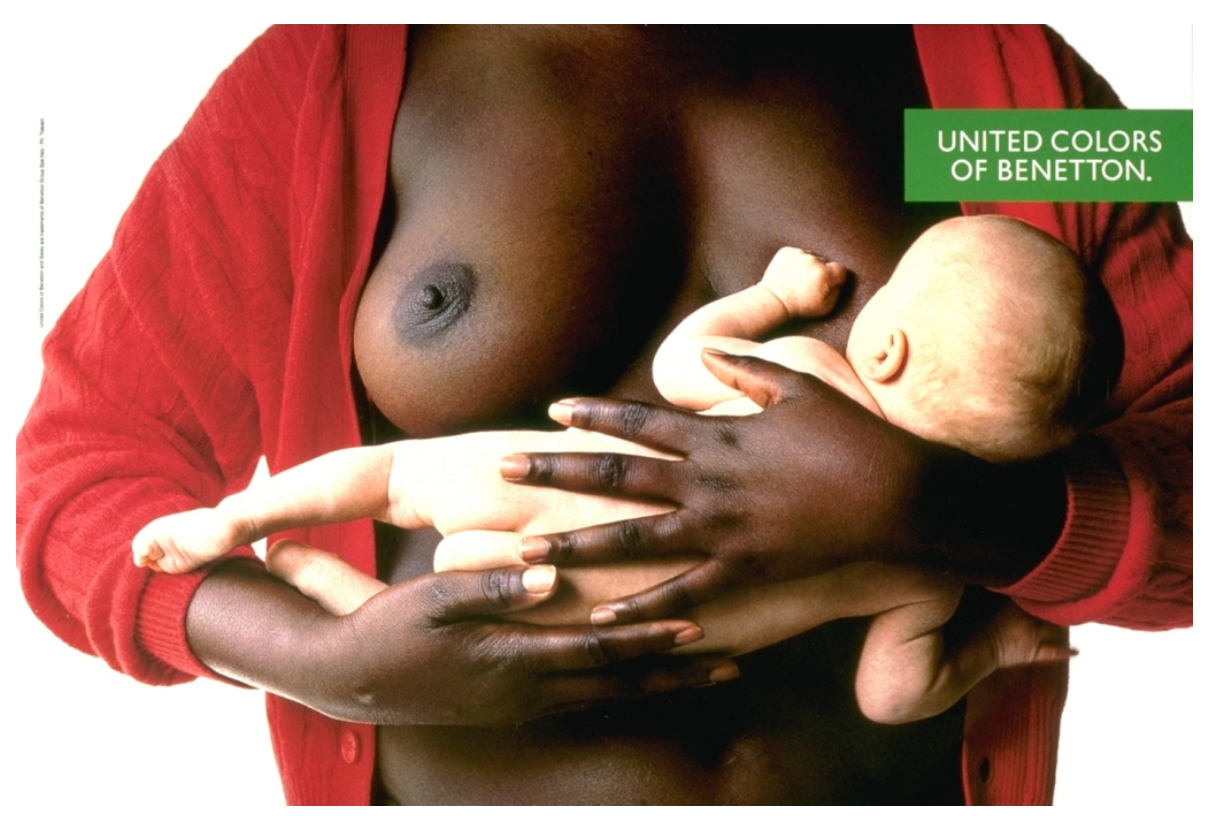

Figure 2. Black woman breastfeeding white baby, September 1989

Photographer: Oliviero Toscani. Source: http://press.benettongroup.com

This campaign created a scandal in America and UK since it was, supposedly, directly referring to slavery, since slaves used to breast-feed the children of slave-owners. Back and Quaade dealt with both the issue of race discrimination and the issue of ambiguity. This specific way of framing - leaving out the head and the face of the black woman, so that she loses her identity - is quite common in art. It is not necessary to insist on someone's character if it does not convey a message. It is the way of framing that completely dehumanizes the black woman in the photo (Back \& Quaade, 1993)

The authors think that each piece of art has historical base, and that it is impossible to exclude the spirit of the past from it or to leave out the social character. Therefore, a political character could be added to the photography. As the head is not shown, and the body is caged within the format of the photo, it symbolizes the inability of free thinking, moving, expressing or even existing.

On the other hand, the woman's breasts are shown, which can be the reason why her character is not present, or it can be that her femininity, humanity and fertility are emphasized. Thus we think it is essential to explain the context in which a photo is set and in what purpose it is going to be used, as this is the condition for interpreting its meaning and idea.

This can be exemplified with the work of the photographer Irvin Penn, who uses Dahomey woman framed in the same way as in Toscani's afore described photo (see Figure 3). Placing her out of her natural surroundings, and taking the photo in a studio, Penn objectifies the woman's body, giving it a new meaning. By specific framing of the woman, Penn emphasizes the shape of her body and directs the viewer's attention to the texture of her skin. Using the same way of framing, Toscani accentuates the baby. With this, we want to point that Toscani's intention was not to dehumanize the woman, but to stress the contact between the black woman and the white child, which is in accordance with Benetton's idea of uniting races. 


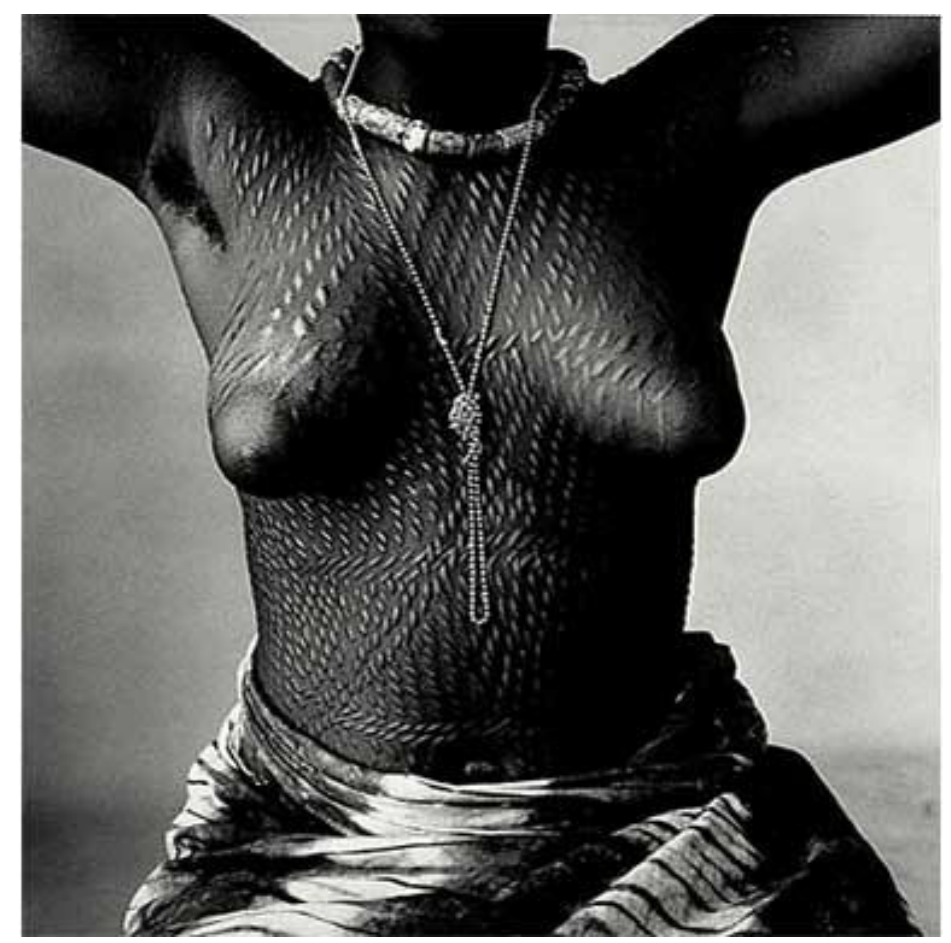

Figure 3. Dahomey, 1967

Photographer: Irving Penn. Source: http://www.freebase.com

The following two photographs will be used to compare different meanings that can be derived from the same contents. The first photograph (see Figure 4) also shows an anonymous woman, but who is of white skin colour as is the child; so we could suppose that she is the child's mother. This photograph shows love between a mother and child. However, in this form, it will hardly be used for advertising purposes. Nevertheless, the manner of its cropping is similar to the previous photograph, but since it is not likely to be put in the same context as the previous one, it would be unfair to discuss it and attach to it some of the attributes as have been done to the previous one.

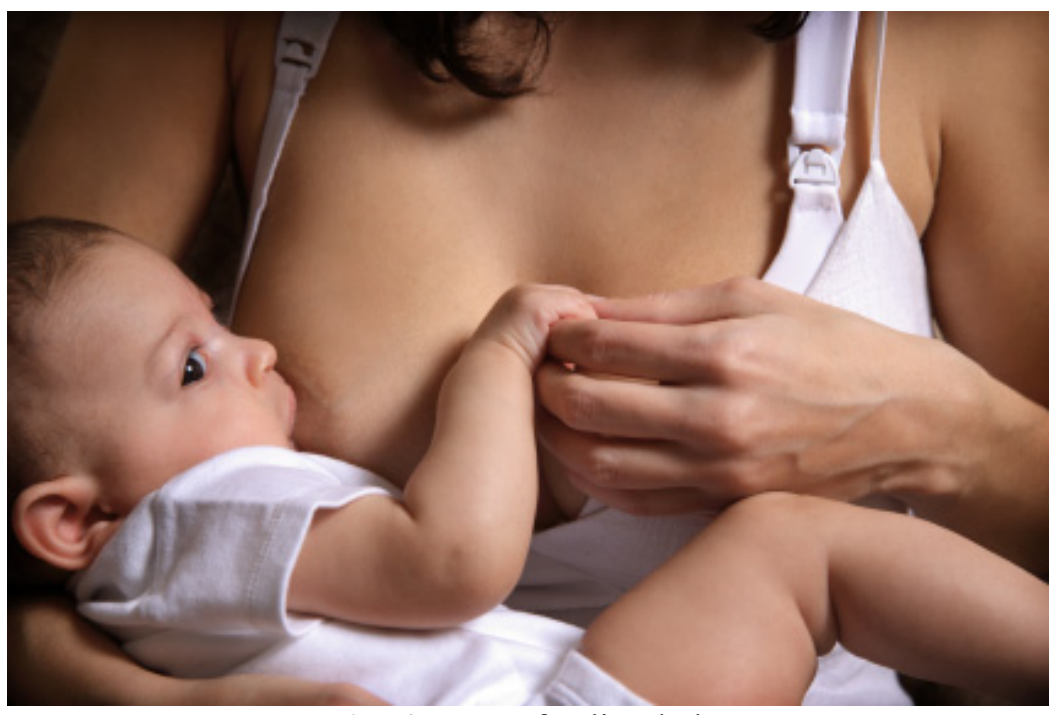

Fig. 4. Breastfeeding baby Source: http://z.about.com 
The following photograph also shows a mother and child of the same colour of the skin, but a child holds tightly to its source of food. The child's intimidated look is in the foreground, which indicates dissatisfaction. The message conveyed by this photograph is about famine in the world, and it is not likely to be used for advertising purposes. The figure is not presented due to copyright of the author Sean Sprague (see http://www.spraguephoto.com)

Depending on the context the photograph is placed in and the purpose of its use, both meaning and significance of a photograph change.

In our opinion Toscani's intention is to shock, but not to infringe on human rights. He does give primacy to the idea of united races and makes allusion to the world piece. His photographs, featuring people of all races, clearly show that we all should be equal- and a fashion brand of Benetton is intended for people of all races and all ages. Victoria Rava, a Marketing Director of Benetton at the time, commented on this case: "We believe our ads should create a shock, otherwise people will not remember them" (Graham, 1989, as cited in Wells, 2006).

\section{Benetton's (Toscani's) Documentary Approach}

In further campaigns (work for the company), Benetton (Toscani) uses poignant documentary photographs that deal with current problems in the world. "Toscani is attempting to create a new style of communication: a stew of art, journalism, social commentary and the kind of advertising that spends big money to argue a point and not to sell illusions" (Mabrey, 2000).

The very aim was to arouse controversy so as to attract as much of the consumer's attention as possible. The aim was not to present information directly and to deal with fashion, but to use current happenings in the world as main attributes of propaganda while raising awareness and information about these problems at the same time.

As a creative director of the campaigns (since 1992), he takes over documentary photos published in the media, placing Benetton's logo on them. "Scandalous violence in the news is normal. However, when you put the same picture and put a Benetton logo on it, people pause and reflect on their position, and the effect becomes more aggressive" (Docshare, 2009).

Using the picture that has been called "the most shocking photo used in an ad," (Lester, 2006) "Toscani tried to exceed the limits of photography genres according to which the "reality" of a documentary photograph is totally opposed to the world of imagination relating to commercial photography" (Wells, 2006, p. 329).

The photograph showing David Kirby (see Figure 5) surrounded by family members shortly before his death from AIDS, the executives of Benetton had taken with the approval of Kirby's parents and used it in the campaign, believing that it would raise AIDS awareness around the world. At that time the knowledge level of the disease was very low, which we can see through the situation described by Lester: "The emergency workers who took him to the hospital later burned everything in the ambulance that Kirby had touched" (2006, p.71). 


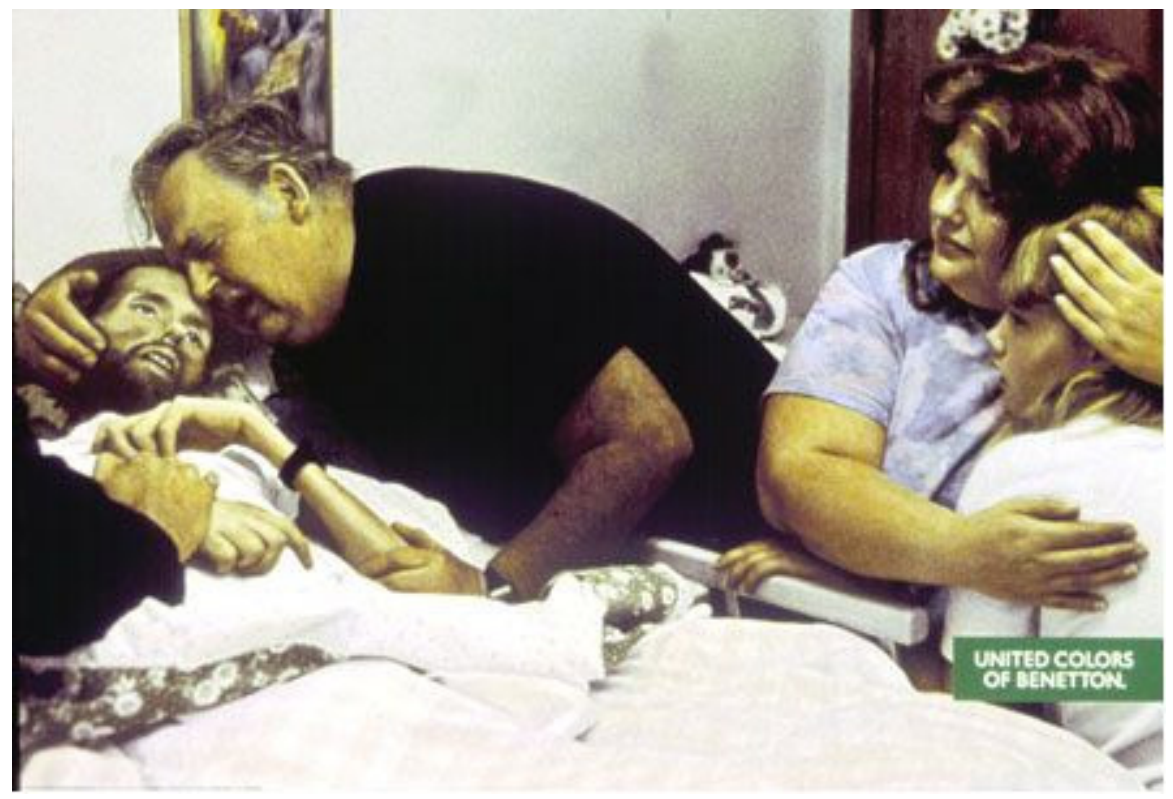

Figure 5. AIDS - David Kirby, 1992

Photographer: Therese Frare. Source: http://press.benettongroup.com

The campaign drew unexpected media attention and faced a number of contradictory opinions. Barb Cordle, volunteer director of the institution where Kirby was hospitalized said, "the picture in the ad has done more to soften people's hearts on the AIDS issue than any other I have ever seen. You can't look at that picture and hate a person with AIDS. You just can't" (Cordle, as cited in Lester, 2006).

The AIDS activists believe that a dying body used in commercial purposes must provoke "horror, anger, and outrage" as Lester stated (2006, p.71). They categorically disapprove of corporation exploiting a personal tragedy to sell a product.

The author's opinion is that regardless of the violent reactions that the campaign caused, shock advertising proved to be one of the best ways of spreading awareness of the social problems. Awareness of the disease is spreading, young people are educating the public through the volunteered work, and the fear of disease is reduced. It is irrelevant Benetton had to compensate the families of the victims of this disease, "the company's profit increased worldwide by 10 percent. As Lester (2006) points out, perhaps most important of all is that they attracted great media attention, and the campaign has proved to be extremely successful.

That same year, after the campaign, Benetton continues to tackle the problem of AIDS. During the Olympics in 1992, they launched a picture of condoms placed in the form of Olympics sign. (see Figure 6). The authors wish to point out the necessity of understanding the context in which the photograph is located. This campaign is much milder, although it deals with the same topic as the previous one. As the actual event they used a sports event, and thus the idea of advocating healthy life is associated with the main idea of the campaign - the prevention of AIDS. The photograph with condoms in various colors is a response to the attitude of the United Colors of Benetton on unifying people. 


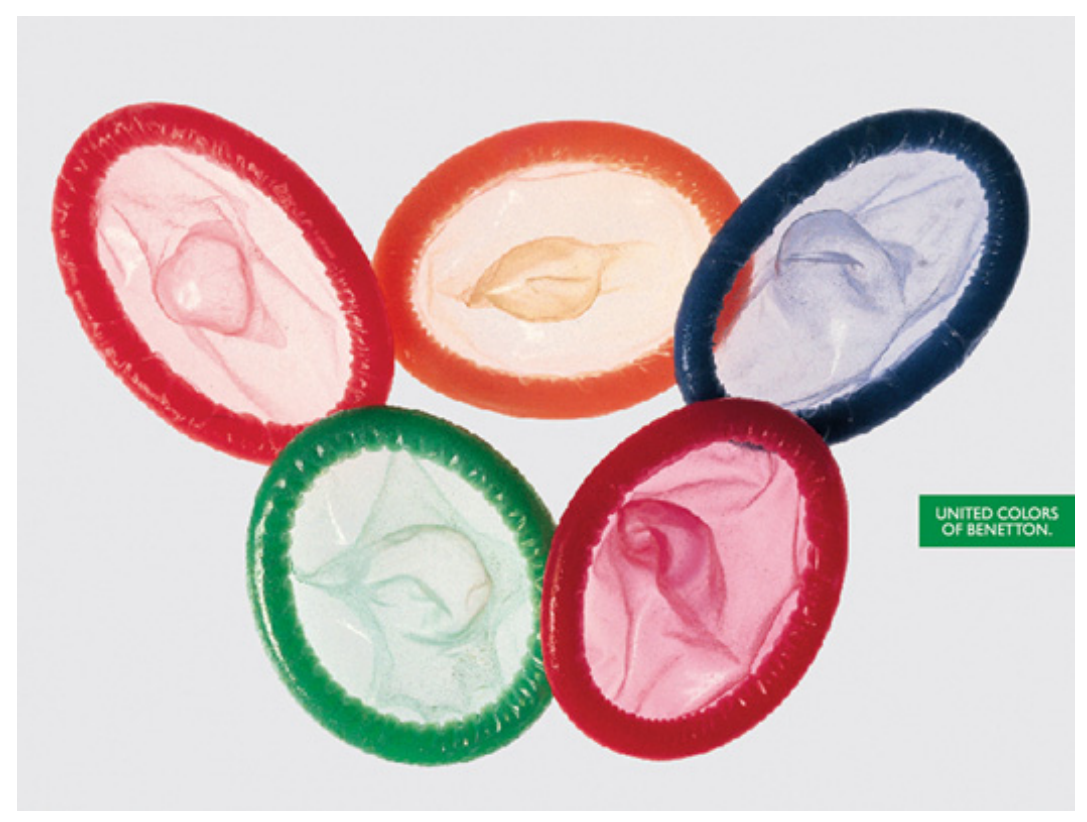

Figure 6. Olympic games, 1993

Photographer: Oliviero Toscani. Source: $\underline{\text { http://press.benettongroup.com }}$

We will analyse differences of the photograph context in the following cases:

This photograph (see Figure 7) contains direct information about protection during sexual intercourse; it is not imaginative and does not give space to think deeper, which is not necessary here. Our assumption is that it belongs to a catalogue or schoolbook and conveys its message directly.

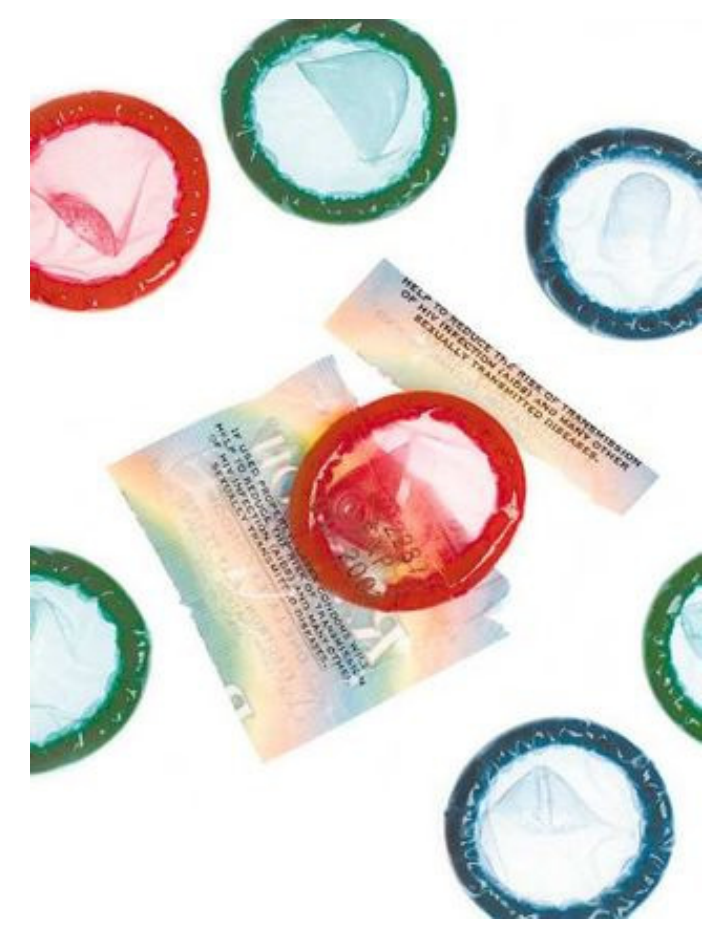

Figure 7. Pick a condom, (almost) any condom Source: http://latimesblogs.latimes.com, 


\section{Culture Advertising Photography}

The following picture (see Figure 8) also provides direct visual information about protection from pregnancy and protection against disease.

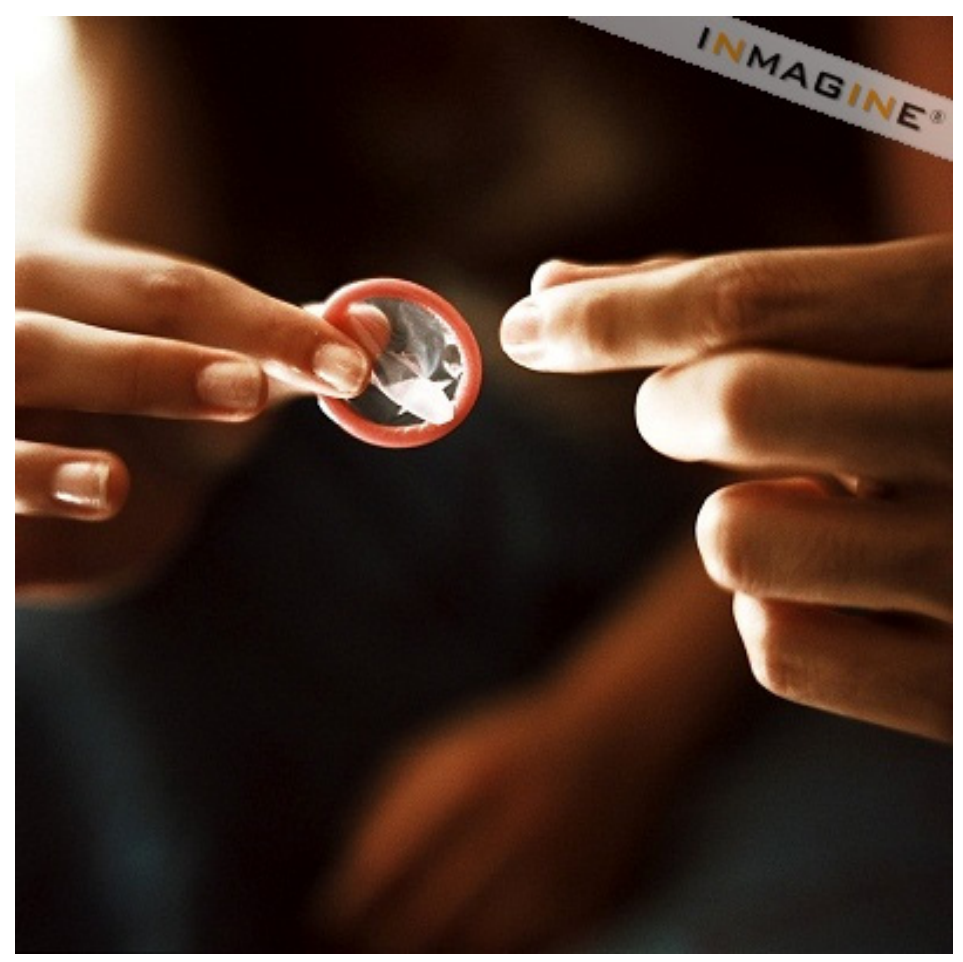

Figure 8. Direct Visual Information

Source: http://www.inmagine.com

A documentary photograph (see Figure 9) featuring a part of production process is even more informative.

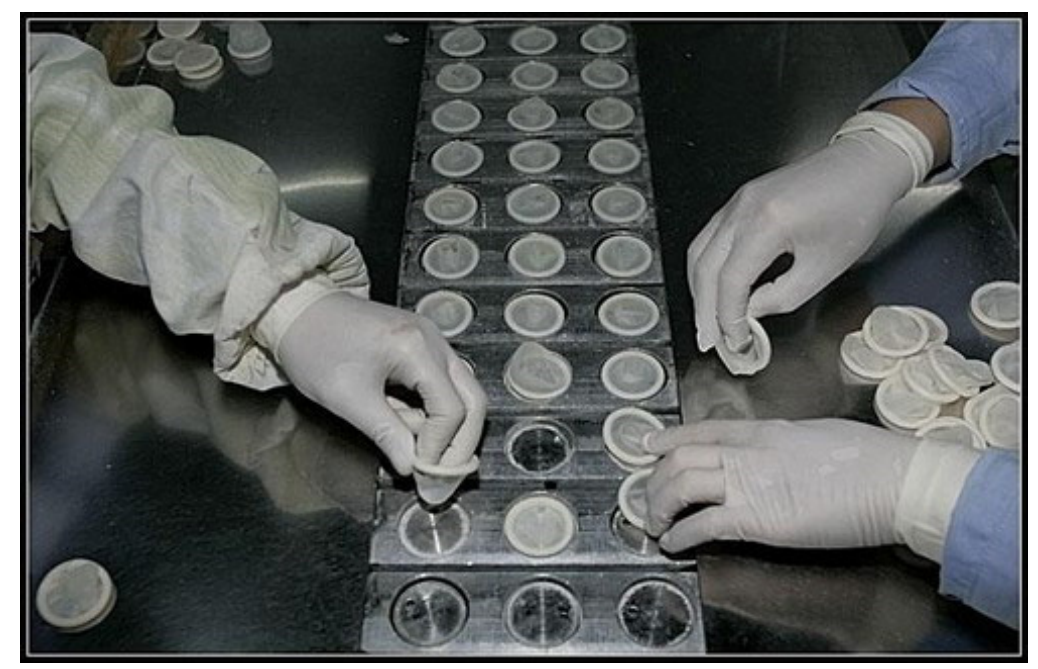

Figure 9. How Condoms were made

Source: http://www.2dayblog.com 
This analysis tries to point out that the concept in which the photograph is located represents a necessary condition for the transfer of the real message, which is the way to profit.

\section{'We, on the Death Row' Campaign in 2000}

During the last year of his cooperation with Benetton, Toscani couldn't employ the "fashionable ambiguity" of his previous campaigns when he made the photographs of the American condemned prisoners. The situation was such that he could not convert this theme into a spectacle. He used the photograph in order to express his revulsion against capital punishment and unfairness of the judiciary (Wells, 2006). However, this turned into a counter-campaign.

"Benetton, the Italian clothing manufacturer, has been making more news with its advertising lately than with its fashions. In its latest ad campaign, the company is spending \$20 million to tell the world that the death penalty in America is barbaric" (Mabrey, 2000).

The photographs of 26 condemned prisoners, which were made in American prisons over a period of two years, appear on 96 pages of Benetton's catalogue published in Talk magazine (see Figure 10). The criminals wearing prison clothes were presented as being victims themselves. There was a text in capital letters "sentenced to death" written across every photograph, as well as some detailed information about each of the victims of the condemned.
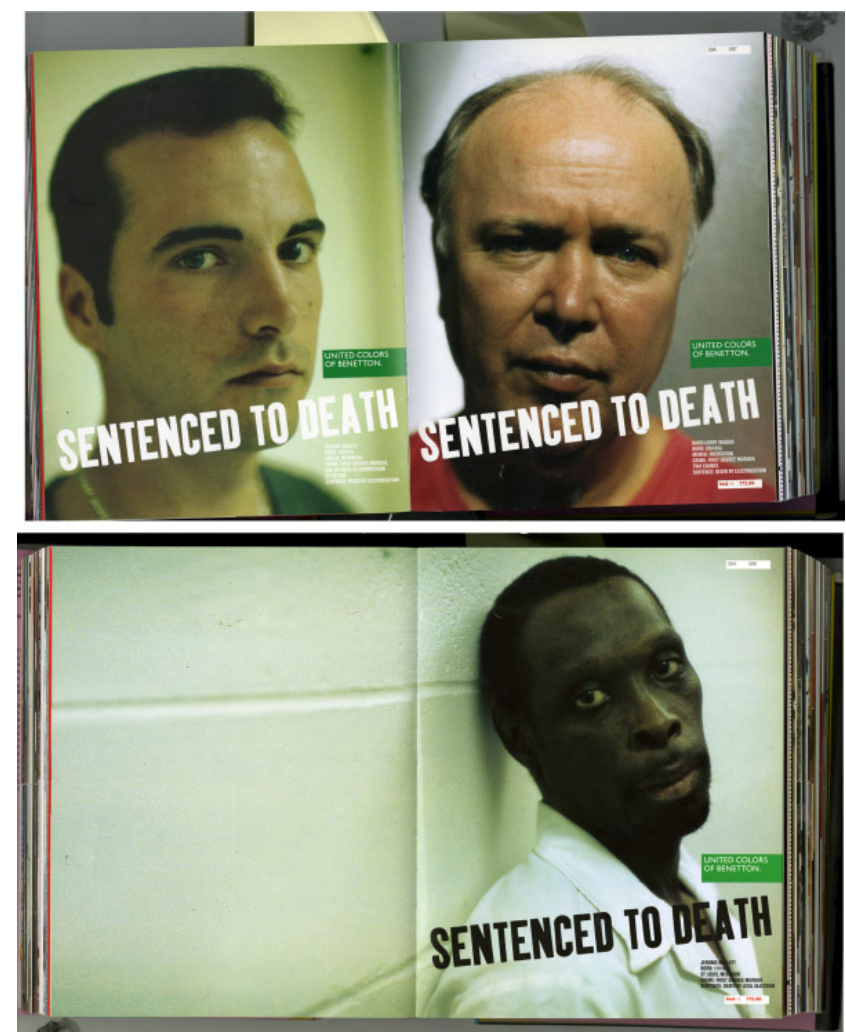

Figure 10. Benetton catalogue, Spring - summer 2000 campaign Source: http://pandakingdesign.com

It was not only for the message of the campaign that provoked controversy, but it was also for the way Benetton did it. Many people think that this campaign glorifies the convicted murderers. The State of Missouri took legal action against Benetton because of this campaign, while Sears (Sears, Roebuck and Co. - American mid-range department store chain well-known for its catalogue-based sales) cancelled the contract for sale of Benetton clothes. The State of Pennsylvania also joined in the criticism of the campaign and called for a boycott of Benetton products. The 
members of the victims' families were outraged by the campaign whose stars were murderers. The Sears company, whose target market was Middle West and customers of mainly conservative attitudes, acted immediately upon hearing the representatives of the victims' families speak against the campaign. Furthermore, the victims' parents held protests in front of Benetton's American head office in New York.

"Maybe we didn't fully calculate the emotional reaction it was going to cause," said Frederico Santor on behalf of Benetton (Usborne, 2000).

Toscani himself said that there was no doubt of the condemned prisoners' guilt and that he undoubtedly sympathized with the members of victims' families. However, in Benetton's catalogue of killers Toscani and his team did not question the condemned prisoners about the reasons for committing their crimes or whether they would do it again. Neither did they ask about the details of the murders.

Toscani said that he did not intend to evoke sympathy towards the murderers. He just considered them as human beings after all.

Some leading figures in the world of advertising attacked Toscani's work. "To try to sell sweaters over basically dead bodies of murdered victims is in the worst taste and in the worst possible judgment," said Jerry Della Femina, who wrote, designed and sold many advertisements (Mabrey, 2000).

Benetton is a very successful company: 7000 shops in 120 countries including the USA. Benetton's profits are on rise worldwide except for America where the number of shops decreases. Benetton's sales in America also fell. The company received letters from people saying that they would never again buy Benetton products.

In reaction to the cancellation of the contract between the company of Sears and Benetton, which resulted from this campaign, Toscani said that "Sears is an old-fashioned company and that it is necessary for Benetton to have a modern partner" (Mabrey, 2000).

A couple of months later, Toscani and Benetton's cooperation came to an end.

This example clearly speaks of the limitations of marketing; but when politics gets involved in a way that is opposite to current ideology, such situation entails disapproval and failure; given the fact that the aim both of marketing and a state is profit. Luciano Benetton stated after this incident: "Running of the company is not in my line of work; I am an entrepreneur by profession" (Benetton as cited in Wells, 2006).

We are convinced that the failure of the campaign happened due to Toscana's inadequate selection of the theme, which was his personal attitude, contempt toward the death penalty, and that finally led to the termination of the contract with Benetton. Authors think that the campaign had too strong political character and that it was a direct attack on the state and the judicial system. The state, creative thought and campaign's profit can't be put in equal positions. We do not know how a company is thought to justify their opinions directly to the judicial system. Based on Toscani's statement, we are convinced that it was a planned break with the company Benetton.

Authors believe that "Sentence to death", was not risky and imprudent campaign. Since in the beginning Benetton wanted to enter the rich American market, in this environment it extinguishes. At least with Toscani's ideas, namely, America as a country of an incredibly rapid growth, quickly exhausted the idea of Benetton (Toscani), so that it is not an accident that the cooperation between Benetton and Toscani ends, because it is rapidly becoming an inadequate market. Profit was not satisfactory. We think Toscani knew that in advance, so he could engage himself in very risky game of advertising. 
However, Toskani and Benetton were not naïve at all. Besides shocking ads and controversy, the company has always had a back up, sweetish and potable studio photographs, which are mainly consumed by catalogs and magazines, and were a guarantee that the "colorful" products will sell.

\section{Diffusion of Fine Art Works}

Exhibition as a basic form of the diffusion of works of fine art, depending on their character, idea, informative level they contain, purpose and other factors, has to be adapted to the space where it is presented. Closed exhibition space can be found in: museums (retrospective and other larger exhibitions), art galleries, commercial galleries, gallery space of cultural centres and other nonprofit institutions, gallery-bookshops or café-gallery, gallery-shops, gallery space in companies: factories, banks etc, as well as restaurants, shops, faculty lounges ... and other space which is not specially designed for exhibition purposes. Open public space like streets, parks, and promenade more and more often become public galleries where lots of people gather as they are easily accessible.

We will show some ways of exhibiting advertisements, the influence of the ambience and its combination with other elements. . It is important to have as attractive place as possible, one busy with people. Avoiding cliché and introducing new or some incompatible types of settings contribute to stronger influence of visual expression.

The $21^{\text {st }}$ century brings about some radical changes to presentation of fine art so that we can more frequently see exhibitions organized in out-of-gallery space. Technological and technical inventions enable arts to be presented in modern ways. Thus street billboards, in addition to advertising campaigns of highly informative and aesthetic value, often show fine art or, even more frequently, photo exhibitions. Street LED screens of big formats enable moving pictures, even sound...

The aim of the new, alternative exhibition space is to have information transmitted to consumers as fast as possible and to attract attention through being a "novelty". Hence the context and ambience in which the photograph is set assume a decisive role.

Works of art displayed on mobile toilets are definitely eye-catching. Except for being conspicuous and combined with material on which they are displayed, they also have a symbolic meaning.

Gallery space. The combination of elements and its concept are important; contrast and the type of setting.

\section{Conclusions}

The Benetton Company did not mean to upset people. Its aim was not merely to make profit, but to prove that art serves its cause. Toscani wanted to present his artistic ideas and to show that a way of thinking can be profitable and that all knowledge is paid for. Today, the connection of art, with all its attributes, and its launching with profitable purposes is very complex. Hence, the marketing campaign of this company united education, the study of current social problems, the creation of beautiful, a way to profit, and laying a path to freedom of thought and expression. Thus, we want to point to the fact that a number of things has to come together in order to create a harmonic community, aiming at the survival of the planet and existence of the human race in general.

Advertising is the richest and more powerful form of commercial comunication in the world.

The modern way of advertising, as we have concluded according to the previous text, introduced great innovations in expression and the way of communicating with the public or consumers. Actually, we have seen that a modern advertisement does not necessarily have to be direct informa- 
tion, but current social, economical and other similar problems become major means of communication, which of course remain a significant historical record of the particular period of time.

An image is the fastest means of conveying information. Illiterate children, acknowledge visual information first as a fact (an innate instinct of recognition). In our opinion, shock advertising is an ideal way of promoting a brand, no matter if the reactions are positive or not. Any controversy leads to discussion, initiates a dialogue between people with different points of view. The reason for the ad campaign is to make people think, to get them talk about serious issues, and to promote worldwide multiculturalism.

The aim of the authors is to prompt and remind artists that art does not merely evoke positive emotions, the sense of beautiful, but that it has its purpose. Through visual media it educates people and keeps reminding them of important world issues in order to resolve them. By solving world issues, and harmonizing social, economic and political relations, it is easy to reach the target-profit, which is today a precondition for a normal life.

The production and distribution of information are class dependent; the ways of updating information and region where it is realized particularly depend on proprietary relations and the rules of the market. Depending on its context, a photograph can even convey such a message. Undoubtedly, culture and tradition, social, economic or political status all assume a leading role regarding presentation of information. On the other hand, the way a photograph communicates with the public and the type of visual presentation it communicates are of immense importance, i.e. there has to be a suitable social setting. The manner in which information or a type of information is presented does matter in terms of whether it is presented as goods on the market or, contrary to this, as knowledge.

What is absurd about Toscani's photographs is the fact that contents presented by them bear no relation to the fashion brand, actually.

\section{Reference}

Back, L.,\& Quaade, V. (1993). Dream utopias, nightmare realities: Imagining race and culture within the world of Benetton. (third tekst. No 22)

Docshare. (2009). Case analysis Benetton. Retrieved from http://www.docshare.com

Dragicevic Sesic, M. \& Dragojevic, S. (2005). Menadzment umetnosti u turbulentnim okolnostima [Management of Art in turbulent circumstances]. Beograd: Clio

Dragicevic Sesic, M., \& Stojkovic, B. (2007). Kultura: Memadzment, animacija, marketing [Culture: Management, animation, marketing] (5th ed.). Beograd: Clio

Giddens, E. (2005). Sociologija [Sociology]. Ekonomski fakultet Univerziteta u Beogradu, Beograd

Lester, P. M. (2006). Visual communication: Images with messages (4th ed.). USA: Thomson Wadsworth.

Mabrey, V. (2010). Catalog of killers, the stars: Death row murderers. Retrieved from http://www.cbsnews.com/stories/2000/05/30/60II/main200723.shtml

Nye, D. (1985). Image worlds: Corporate identities at General Electric 1890-1930. Cambridge, MA: The MIT Press

Ramamurthy, A. (2003). Imperial persuaders: Images of Africa and Asia in British advertising. Manchester University Press

Usborne, D. (2000). Benetton death row ads outrage America. Retrieved from http://www.independent.co.uk/news/world/americas/benetton-death-row-ads-outrage-america719129.html

Wells, L. (2006). Fotografija: Kritički uvod [Photography: A Critical Introduction]. Beograd: Clio 


\section{Biographies}

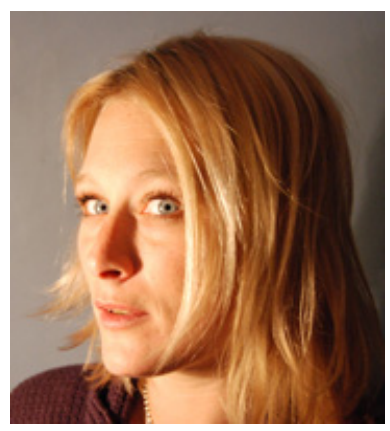

Sibila Petenji Arbutina, born 1976, is a lecturer at the Higher Technical School of Professional Education, Novi Sad, Serbia. She teaches photography courses: Applied Photography course and Theory and Visual Elements of photography. She holds a MS in Graphic Art at Academy of Art, Novi Sad. She had 10 solo and many group exhibition. Her professional fields of interests are photography, design, painting, and multimedia art.

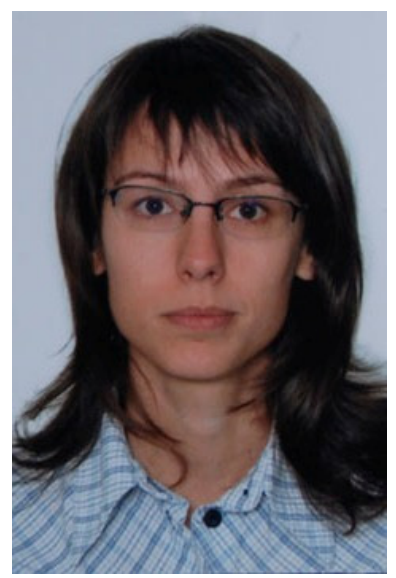

Jelena Kovačević Vorgučin, born 1975, is an assistant professor at Academy of Arts in Novi Sad, and lecturer at the Higher Technical School of Professional Education, Novi Sad, Serbia. She teaches photography courses: History and Aesthetic of Photography and Documentary Photography. She holds a MS in Photography at Faculty of Applied Arts in Belgrade. She had 8 solo and many group exhibition. Her professional fields of interests are photography, advertizing, design, and multimedia art. 